Ritrýnd grein birt 31. desember 2021

\title{
Myndbandasamkeppnin Siljan: Lærdómur af lestrarhvetjandi verkefni
}

\author{
Brynhildur Pórarinsdóttir
}

Abstract

- Um höfund

About the author

Heimildir

Myndbandasamkeppnin Siljan er skapandi lestrarverkefni fyrir nemendur í 5.-10. bekk, en pað er Barnabókasetur sem stendur fyrir keppninni. Nemendur velja nýlega barnaeða ungmennabók og hafa frjálsar hendur við að skapa myndband um hana. Markmiðið er að efla lestraráhuga grunnskólanemenda, stuðla að jafningjahvatningu og beina sjónum skólasamfélagsins að barna- og ungmennabókum. Barnabókasetur nýtir keppnina jafnframt til að safna gögnum sem nýst geta til að bæta lestrarmenningu barna og unglinga. Siljan hefur verið haldin sex sinnum og í gagnasafninu eru 230 myndbönd eftir nærri 800 nemendur. Hér verður gagnasafn Siljunnar krufið, hópurinn að baki myndböndunum verður greindur og litið sérstaklega á framlag stúlkna og drengja sem og miðstigsnemenda og unglinga. Pekking á lestrarvenjum grunnskólanemenda gefur tilefni til að ætla að stúlkur taki frekar pátt í lestrartengdu verkefni en drengir og yngri nemendur frekar en eldri. Hvort tveggja fékkst staðfest en pó hallar enn meira á unglingana en búast hefði mátt við. Pótt almennt halli á drengi mæta peir sterkir til leiks par sem kennarar tóku keppnina inn í kennsluna, sem sýnir hversu mikilvægur páttur kennarans er í að skapa stemningu fyrir lestri. Fjallað verður um bækurnar sem nemendur völdu í samanburði við metsölulista og útlánatölur skólasafnanna, hvað einkennir vinsælustu bækurnar og hvað einkennir myndböndin en slíkar upplýsingar um hvernig börn velja og túlka bókmenntir koma að gagni við eflingu læsis og bókmenntakennslu. Myndbandasafnið ber vott um sköpunarkraft, hugvitssemi og tæknifærni barna og minnir á mikilvægi pess að vinna með áhugahvöt í tengslum við læsi.

Efnisorð: Lestrarhvatning, læsi, skapandi skólastarf, upplýsingatækni, bókmenntakennsla

\section{Inngangur}

Myndbandasamkeppnin Siljan er skapandi lestrarverkefni sem nemendum í 5.-10. bekk í grunnskólum landsins býðst að taka pátt í. Pað er Barnabókasetur, rannsóknasetur um barnabókmenntir og lestur barna við Háskólann á Akureyri, sem stendur fyrir keppninni, síðustu ár í samvinnu við Borgarbókasafnið í Reykjavík. Markmiðið með keppninni er að hvetja börn og unglinga til að lesa og tjá sig um bækurnar sem pau lesa, og samhliða pví að beina sjónum skólasamfélagsins að barna- og ungmennabókum.

Siljunni var komið á laggirnar skólaárið 2014-2015 en verkefnið varð til sem viðbrögð við niðurstöðum rannsókna á lestri barna og unglinga. Langtímarannsóknir á lestrarvenjum sýndu að dregið hefði úr tómstundalestri íslenskra grunnskólanemenda. Börn á aldrinum 10-16 ára læsu sjaldnar sér til ánægju en áður og hlutfallslega færri væru í hópi stórlesenda (Porbjörn Broddason o.fl., 2009). Mælingar á lesskilningi sýndu einnig hnignandi árangur. Samkvæmt PISA-könnunum OECD hafði 
íslenskum nemendum í 10. bekk farið aftur um sem nam hálfu skólaári milli áranna 2000 og 2012 (Almar M. Halldórsson o.fl., 2013). Jafnframt lá fyrir að mikill kynjamunur væri í lestraráhuga, stúlkur læsu mun oftar en drengir utan skóla og mun fleiri drengir höfnuðu bóklestri (Brynhildur Pórarinsdóttir o.fl., 2012; Porbjörn Broddason o.fl., 2009). Pessi kynjamunur birtist einnig í PISA-könnununum par sem kynjamunur stúlkum í hag hafði komið fram í öllum lesskilningsprófunum frá 2000 og mun fleiri drengir en stúlkur sátu á lægstu hæfnisprepunum í lesskilningi (Almar M. Halldórsson o.fl., 2013).

Rannsóknir bentu einnig til pess að lestraráhugi og -árangur héldust í hendur. Niðurstöður PISA-könnunarinnar 2009 drógu fram tengsl milli áhuga á lestri og árangurs í lesskilningi. Ánægja af lestri var sá matspáttur sem sterkast tengdist árangri í lesskilningi (Almar Miðvík Halldórsson, 2011). Munurinn reyndist samsvara allt að einu og hálfu skólaári milli peirra bókhneigðu og hinna sem sögðust ekki lesa sér til ánægju (OECD, 2011). Hnignandi árangur í lesskilningi mátti pví tengja við minnkandi tómstundalestur. Pegar rýnt var í tómstundalestur bentu rannsóknir til pess að viðhorf barna til lestrar hefðu jafnvel meiri áhrif á hversu mikið pau læsu en færni peirra í lestri. Kynjamun í lestrarvenjum mætti að vissu marki skýra með pví að stúlkur hefðu almennt jákvæðara viðhorf til lestrar en drengir (Logan og Johnston, 2009). Pá höfðu rannsóknir á ungum bókaormum sýnt að peir ættu pað sameiginlegt að hafa alist upp við lestur og hefðu lestrarfyrirmyndir á heimilinu (Kristín Heba Gísladóttir o.fl., 2013).

Pað benti pví margt til pess að vinna pyrfti með hugræna og félagslega pætti ef árangur ætti að nást í lestrarmálunum, p.e. áhuga, viðhorf og venjur. Siljunni var ætlað að leggja lóð á pessar vogarskálar. Keppnin var hönnuð út frá peirri hugmyndafræði að leiðin til að bæta lestrarvenjur barna og unglinga lægi um áhugasvið peirra og félagslíf. Mikilvægt væri að gera lestur barna og unglinga sýnilegri, styrkja jákvæðar lestrarfyrirmyndir innan hópsins og virkja unga lesendur til jafningjahvatningar.

Siljan hafði frá upphafi bæði fræðilegt og hagnýtt markmið. Með keppninni hugðist Barnabókasetur safna gögnum sem nýst gætu til að vinna að bættri lestrarmenningu meðal barna og ungmenna. Siljan hefur nú verið haldin sex sinnum og framlög pátttakenda mynda gagnasafn sem ber vitni um áhugasvið og sköpunarkraft grunnskólanemenda. Í pessari grein verður dregin upp mynd af pessu gagnasafni sem geymir 230 myndbönd eftir nærri 800 nemendur. Hópurinn að baki pessum myndböndum verður greindur og skoðað hvert framlag stúlkna og drengja er til heildarsafnsins. Аð sama skapi verður skoðað hvernig skiptingin er milli miðstigsnemenda og unglinga. Fjallað verður um bækurnar sem nemendur völdu að vinna með við gerð pessara 230 myndbanda, en bókavalið gefur vísbendingar um hvers konar efni höfðar til barna á ákveðnum aldri. Skoðað verður hvað einkennir bækurnar sem njóta mestra vinsælda og að sama skapi hvað einkennir framlög barnanna. Loks er lærdómurinn af keppninni settur í samhengi við rannsóknir á lestri barna og unglinga í von um að greinin komi að gagni við eflingu lestraráhuga meðal grunnskólanemenda og par með bætingu lesskilnings.

\section{Lestur og bókmenntir í grunnskólum}

Læsi íslenskra unglinga, einkum drengja, veldur stöðugt áhyggjum og hnignandi árangur í lesskilningi er reglulega harmaður á opinberum vettvangi. Læsi skólabarna var sîđast rætt á Alpingi 25. maí 2021 pegar mennta- og menningarmálaráðherra svaraði fyrirspurn um námsárangur pilta og stúlkna í íslenska skólakerfinu (pingskjal nr. 1455/2020-2021) og rataði paðan í fréttir á RÚV sama dag undir fyrirsögninni „Lesskilningur drengja vel undir meðaltali OECD“ (Magnús Geir Eyjólfsson, 2021). Hafa parf í huga að lesskilning er hvorki einfalt að mæla né hafa skilgreiningar verið einhlítar. Sigríður Ólafsdóttir og Baldur Sigurðsson (2017) rekja hvernig lesskilningshugtakið hefur próast og dýpkað í takt við tímann. Lesskilningur snýst ekki aðeins um að skilja pað sem maður les heldur að geta unnið úr pví. OECD ítrekaði í tengslum við PISA-könnunina 2018 að mælingar á lesskilningi snerust um meira en að lesa og skilja. Nemendur pyrftu að geta sett textann í samhengi og dregið ályktanir út frá peirri pekkingu sem peir byggju yfir. Peir pyrftu að geta greint sjónarhorn höfundarins og áttað sig á hvort textinn væri áreiðanlegur og réttur og hvort hann skipti máli fyrir pað sem 
peir eru að gera (OECD, 2019). Hin formlega skilgreining sem lögð var til grundvallar lesskilningsprófunum 2018 var orðuð pannig: Lesskilningur er „... hæfni til að skilja, meta, nýta sér, ígrunda og ástunda lestur á rituðum texta í peim tilgangi að ná markmiðum sínum, próa pekkingu sína og hæfni og taka virkan pátt í samfélaginu“" (Menntamálastofnun, 2019).

Pegar pessi skilgreining á djúpum lesskilningi er lögð til grundvallar verður útkoman sú að vanir lesendur standa sig betur en óvanir, peir eiga auðveldara með að átta sig á nýjum orðum út frá samhenginu og gera pær tengingar sem parf til að draga ályktanir. Segja má að lesskilningskönnun PISA mæli fyrst og fremst hversu víðlesin börnin eru; hversu mikið pau ástunda lestur. Par vinna stúlkurnar í öllum pátttökuríkjum OECD; í hverju einasta ríki urðu stúlkur ofar drengjum, eins og fram kom í svari ráðherra á Alpingi (pingskjal nr. 1455/2020-2021). Pessi kynjamunur í lesskilningi endurspeglar sem fyrr segir pann kynjamun í lestrarpjálfun sem kemur skýrt fram í fjölpjóðlegum mælingum á lestrarvenjum. Evrópska ESPAD-rannsóknin sýnir t.d. að stúlkur lesa að jafnaði oftar bækur en drengir í öllum pátttökulöndunum (Brynhildur Pórarinsdóttir o.fl., 2012, 2017).

Ýmsar rannsóknir hafa verið gerðar á pessu sviði á undanförnum árum sem dýpkað hafa skilning á samspili lesskilnings og annarra pátta. Freyja Birgisdóttir (2016) sýndi fram á að orðaforði er langsterkasti forspárpátturinn fyrir slakt gengi í lesskilningi í PISA-könnununum. Freyja setur slakan orðaforða í samhengi við lítinn lestur og bendir á að meirihluti peirra nemenda sem sitja á lægstu hæfnisprepunum lesi aldrei sér til gamans, almennt lesi pessi hópur sjaldnar utan skóla en aðrir nemendur og fábreyttara efni, auk pess sem viðhorf pessara nemenda til lestrar sé almennt neikvæðara.

Lesskilningur hefur einnig verið skoðaður út frá virkni nemenda en rannsóknir á virkri pátttöku nemenda í skólastarfi sýna mikinn kynjamun stúlkum í hag, rétt eins og rannsóknir á lesskilningi. Sigrún Jónatansdóttir, Kristján Ketill Stefánsson, Steinunn Gestsdóttir og Freyja Birgisdóttir (2017) sýndu fram á að kynjamun í lesskilningi á unglingastigi væri hægt að skýra með almennt meiri pátttöku stúlkna og almennt minni pátttöku drengja í skólastarfi. Pau benda pví á að gagnlegt geti verið að huga sérstaklega að stuðningi við virka pátttöku í skólastarfi til viðbótar við aðra pætti kennslu.

Pá hafa rannsóknir einnig beinst að yngri nemendum. Pannig sýndu Hafdís Guðrún Hilmarsdóttir, Freyja Birgisdóttir og Steinunn Gestsdóttir (2018) fram á að framfarir í lesskilningi milli 5. og 6. bekkjar tengjast ekki aðeins færni í lestri heldur líka lestraráhugahvöt. Stúlkur á pessum aldri hafa að meðaltali meiri lestraráhuga en drengir og forðast síður lestur. Pær benda á að sambandið virkar í báðar áttir, góð færni î lestri ýtir undir áhuga og áhugi á lestri eflir færni.

Ástundun og áhugi virðast pví vera lykilorð við eflingu læsis. Í aðalnámskrá grunnskóla er gert ráð fyrir að unnið sé með pessa pætti pví námskráin gerir ráð fyrir að nemendur læri ekki aðeins að lesa heldur „verði lesendur" í grunnskólanum. Pannig er gert ráð fyrir að nemendur eflist jafnt og pétt sem sjálfstæðir lesendur, t.d. er ætlast til pess að peir pjálfist í að velja sér lesefni. Hæfniviðmið aðalnámskrár gera ráð fyrir að við lok 7. bekkjar geti nemandi lesið gamlar og nýjar bókmenntir, m.a. „bókmenntir ætlaðar börnum og unglingum“ og hann á að geta valið sér „fjölbreytt lesefni við hæfi til gagns og ánægju“. Við lok 10. bekkjar á nemandi að geta lesið, túlkað, metið og fjallað um bókmenntir, og hann á að geta „valið sér lesefni til gagns og ánægju og komið fram sem sjálfstæður lesandi sem gerir sér grein fyrir gildi pess að lesa“ (Mennta- og menningarmálaráðuneyti, 2013, bls. 102-103).

Pessi mótunarpáttur virðist pó mæta afgangi í skólastarfinu. Eins og rakið er í skýrslu Menntamálastofnunar um PISA-könnunina 2018 (Menntamálastofnun, 2019) ber rannsóknum saman um að dregið sé úr markvissum áherslum í lestri eftir 3.-4. bekk. Auður Magndís Leiknisdóttir o.fl. (2009) orða pað svo að á mið- og unglingastigi sé ekki lengur um eiginlega lestrarkennslu að ræða og stefnuleysi ríkjandi í lestrarmálum. Stefnuleysi eða ráđaleysi var einnig nefnt í rannsókninni Íslenska sem námsgrein og kennslutunga (ÍNOK). Hugtakið lesskilningur reyndist valda togstreitu í skólastarfi og skilgreining pess vera á reiki. Kennarar sem rætt var við lýstu ítrekað yfir áhyggjum af lestrarvenjum nemenda, peir höfðu reynt ýmsar leiðir til að fá nemendur til að lesa og kölluðu eftir björgum (Brynhildur Pórarinsdóttir og Kristján Jóhann Jónsson, 2018). 
ÍNOK-rannsóknin sýndi enn fremur að hin neikvæða opinbera orðræða um árangur í PISA-könnununum hefur haft áhrif inn í skólana, ekki aðeins á kennarana heldur einnig viðhorf nemenda (Brynhildur Pórarinsdóttir og Kristján Jóhann Jónsson, 2018). Petta er áhyggjuefni pví viðhorf nemenda til lestrar hafa áhrif á hvort peir sækjast í eða forðast lestur. Hafdís Guðrún Hilmarsdóttir, Freyja Birgisdóttir og Steinunn Gestsdóttir (2018) nota hugtakið lestrarfælni um pað að forðast lestur. Pær sýna fram á að kynjamunur kemur fram bæði í lestraráhuga og lestrarfælni á miðstigi, stúlkur hafa að jafnaði meiri lestraráhuga en drengir sýna að meðaltali meiri lestrarfælni. Hvort tveggja tengist síðan árangri í lesskilningi, lestraráhuginn á jákvæðan hátt en lestrarfælnin á neikvæðan hátt.

Eins og pær Hafdís Guðrún, Freyja og Steinunn (2018) benda á felst mikill ávinningur í að vekja áhuga nemenda á lestri og viðhalda honum. Pað skiptir ekki síður máli að koma í veg fyrir að nemendur fari að forðast lestur eða lestrartengdar athafnir. Ýta purfi undir lestraráhuga með pví að sjá til pess að nemendur hafi aðgang að áhugaverðu efni og gæta pess að peir forðist ekki lestrartengdar athafnir. OECD (2011) benti á pað sama eftir PISA-könnunina 2009; að pað væri áskorun fyrir foreldra og kennara að kveikja áhuga barna á lestri með pví að útvega peim lesefni sem peim fyndist bæði áhugavert og skipta máli. ÍNOK-rannsóknin gefur vísbendingar um veika stöðu barna- og unglingabóka í skólunum. Fæstar bókanna sem unnið er með á mið- og unglingastigi eru barna- eða ungmennabækur; bækur sem teknar eru inn í kennsluna eru oft gamlar og bókavalið kennaramiðað. Pótt yndislestur sé víða kominn á dagskrá er lítið gert með bækur sem nemendur lesa sér til gamans. Skólasöfnin ná heldur ekki að fullnægja pörf nemenda fyrir fjölbreytt og spennandi lesefni en allir skólastjórnendur sem rætt er við í ÍNOK-rannsókninni harma slæma stöðu skólasafnanna. Að sama skapi er umhverfi nemenda ekki nýtt til að vekja athygli á bókmenntum sem stílaðar eru á unga lesendur. Barnabækur sáust helst í skólastofum á yngsta stigi en bókum fyrir viðkomandi aldur fækkaði eftir pví sem nemendur eltust. Pannig sáust engar unglingabækur í kennslustofum á unglingastigi eða í framhaldsskólum. Viðhorf nemenda til lestrar urðu að sama skapi neikvæðari eftir aldri, hópur ungmenna upplifir enga ánægju af lestri og tengir orðið bókmenntir við „leiðinleg skólaverkefni“ (Brynhildur Pórarinsdóttir og Kristján Jóhann Jónsson, 2018; Dagný Kristjánsdóttir o.fl., 2018).

Rannsóknir á námsumhverfi og kennsluháttum kallast pannig á við rannsóknir á viðhorfum nemenda til lestrar og lestrartengdra verkefna. Soffía Vagnsdóttir (2021) bendir á að nemendur hafa sterkar skoðanir á hvernig haga beri kennslunni. Nemendur vilja hafa meira val um hvað peir læra og finnst peir sjaldan fá að velja sér viðfangsefni. Samvinnunám höfðar vel til nemenda en miklum meirihluta, eða níu af hverjum tíu, finnst mjög gaman eða frekar gaman að vinna í hópavinnu. Sama hlutfall telur mikilvægt eða mjög mikilvægt að vinna út frá skapandi hugsun. Skapandi nálgun kemur líka fyrir î ÍNOK-rannsókninni; pær kennsluaðferðir sem virtust gefast vel við kennslu bókmennta kröfðust skapandi nálgunar eða tengdu saman bókmenntir og aðrar listgreinar. Athygli vakti hversu margir nemendanna sem rætt var við í ÍNOK-rannsókninni reyndust eiga erfitt með að tala um bókmenntir, enda sáu kennarar ekki endilega tilgang í að kenna bókmenntafræði. Nokkrir kennarar sögðust pó hafa náð árangri í slíkri kennslu með pví að tengja hugtökin við kvikmyndir eða eigin verk nemenda (Dagný Kristjánsdóttir o.fl., 2018).

Ljóst er að snemma byrjar að draga í sundur með peim sem lesa sér til ánægju og fá með pví samfellda lestrarpjálfun og sívaxandi ritmálsorðaforða og hinna sem forðast lestur. Áhugi og árangur fara saman pegar unnið er með læsi, og að sama skapi kallast áhugaleysi á við lestrarfælni og leiða. Раð hlýtur pví að teljast mikilvægt að afla upplýsinga og greina hvað vekur lestraráhuga nemenda. Аð sama skapi er mikilvægt að skrásetja og ígrunda pau lestrarhvetjandi verkefni sem reynd hafa verið í skólastarfi.

\section{Myndbandasamkeppnin Siljan}

Árið 2013 fékk Barnabókasetur styrk úr Barnamenningarsjóði fyrir verkefni sem efla skyldi lestraráhuga og beina sjónum að barna- og unglingabókum. Verkefnið kallaðist „Siljan - sjónvarpspáttur um barnabókmenntir á netinu" (Rannís, 2013) en par myndu ungir lesendur tjá sig um barnabækur. Áherslan var lögð á að börn yrðu ekki piggjendur eða áhorfendur pessa efnis heldur gerendur. „Hlut- 
verk gerandans skapar áhuga en hlutverk piggjandans er líklegt til að drepa niður áhuga," eins og Kristján Jóhann Jónsson (2013) orðar pað í grein sinni um lestur og bókmenntakennslu.

Siljan var kynnt til sögunnar skólaárið 2014-2015 og pá sem samkeppni um gerð bókamyndbanda. Ákveðið var að reglur Siljunnar skyldu vera einfaldar: Pátttakendur myndu velja sér nýja eða nýlega barna- eða ungmennabók á íslensku og búa til tveggja til priggja mínútna myndband um hana. Börnin gætu unnið ein eða í hópi og hefðu algerlega frjálsar hendur um efnistök. Aðalatriðið væri að pau læsu og notuðu hugmyndaflugið og tæknina. Pannig var fyrsta keppnin auglýst (Háskólinn á Akureyri, 2015). Fjallað var um keppnina og hugmyndafræðina sem hún byggðist á í Skólavörðunni í desember 2015. Par er minnt á mikilvægi jákvæðrar nálgunar í lestrarmálunum og að byggja upp smitandi lestrargleði í barnahópnum (Krakkar bestir í að toga aðra krakka að lestri, 2015). Jafnframt er rætt um stöðu skólasafnanna og pátt Siljunnar í að rétta hlut peirra.

Í aðdraganda Siljunnar lá fyrir að staða skólasafna landsins væri slæm. Söfnin höfðu flest orðið fyrir harkalegum niðurskurði við efnahagshrunið 2008 sem enn hafði ekki skilað sér til baka. Bókakaupafé var verulega ábótavant (Brynhildur Pórarinsdóttir, 2011). Ljóst var að erfitt yrði að vinna að lestrarhvatningu án öflugra skólasafna; pau yrðu að hafa bókakost sem höfðaði til barna. Barnabókasetur ákvað pví að aðalverðlaunin í Siljunni skyldu falla skólasafni sigurvegaranna í skaut og leitaði til Félags íslenskra bókaútgefenda um samstarf. Úr varð að félagið lagði til verðlaunafé í formi bókaúttektar að verðmæti 100.000 krónur.

Frá skólaárinu 2015-2016 hefur keppnin verið haldin í tveimur flokkum, 5.-7. bekk og 8.-10. bekk. Sigurvegarar í hvorum flokki hafa aflað skólasafninu sínu eitt hundrað púsund króna bókaúttektar, oftast með stuðningi Félags íslenskra bókaútgefenda. Dómnefnd hefur verið skipuð í hvert sinn og áhersla lögð á að sýna vinnu barnanna virðingu með pví að kalla saman fólk með fagpekkingu á sviðinu. Pannig hafa leikarar, kvikmyndagerðarfólk, sjónvarpsfólk, rithöfundar og kennarar setið í dómnefnd Siljunnar, valið prjú bestu myndböndin í hvorum flokki og skrifað um pau umsögn.

Siljan hefur nú verið haldin sex sinnum og skólasöfn sigurvegaranna hafa fengið samtals 1.100.000 króna virði af yndislestrarbókum. Hundrað púsund krónurnar sem hvert safn hefur fengið til bókakaupa hafa skipt sköpum. Í einum skólanum var nefnt við aðstandendur keppninnar að upphæðin væri hærri en skólasafnið hefði fengið til bókakaupa pað árið. İ̈ örum skóla var sagt að bókaúttektin tryggði að hægt væri að ráđast í yndislestrarátak í skólanum; loksins yrði hægt að kaupa nýjar bækur. Pau skilyrði voru sett strax í upphafi að nemendurnir sem tryggðu skólasöfnunum bókaúttekt fengju að hafa sitt að segja um hvaða bækur yrðu keyptar. Barnabókasetur leggur mikla áherslu á að pað séu bækur sem börn langi til að lesa, ekki handbækur eða orðabækur pótt skólann kunni að vanta pær. Sigurvegararnir fá pví að mynda bókaráð með skólasafnskennaranum og að sama skapi fá peir að vera viðstaddir pegar stóri bókakassinn peirra kemur í hús. Markmiðið með pessu er að gera barnabækur sýnilegri og hampa lestrarhestunum pannig að myndist stemning kringum sigurvegarana. Verðlaunin eru afhent með viðhöfn í viðkomandi skóla og sigurmyndbandið sýnt við pað tækifæri. Í mörgum tilfellum hefur heilum árgangi verið boðið, jafnvel öllu viðkomandi skólastigi. Í minnsta sigurskólanum var öllum nemendum skólans boðið á verðlaunaafhendinguna. Sigurvegararnir fá seinna að fylla hillur skólasafnsins. Sums staðar hafa peir fengið að bjóða bekknum sínum með eða búa til myndband um komu bókakassanna. Pá njóta peir endurnýjaðrar athygli fyrir bókaáhuga og smita frá sér ánægju yfir nýuppteknum bókum.

\section{Sigurvegarar í Siljunni 2015-2021}

Fyrsta Siljan var haldin í tilraunaskyni vorið 2015. Keppnin náði aðeins til grunnskólanna í Eyjafirði, pað er í nærumhverfi Barnabókaseturs, og gátu nemendur í 5.-10. bekk tekið pátt. Keppnin var auglýst með veggspjöldum sem send voru til skólanna á svæðinu. Níu myndbönd bárust, flest frá Akureyri en einnig frá Svalbarðseyri og Grímsey par sem allir sex nemendur skólans í 5.-8. bekk unnu saman að viðfangsefninu. Рað voru hins vegar tveir piltar úr 7. og 10. bekk Glerárskóla sem báru sigur úr býtum með glettnu myndbandi um Brosbókina eftir Jónu Valborgu Árnadóttur. Skólinn 
fagnaði sigri peirra á vefsíðu sinni og aftur pegar bókakassinn barst til skólasafnsins (Glerárskóli, 2015a, 2015b).

Viðbrögðin við fyrstu Siljunni gáfu tilefni til að próa verkefnið áfram. Siljan 2016 var opin nemendum um allt land og voru veggspjöld send til allra grunnskóla á landinu. Keppninni var skipt í tvo aldursflokka, 5.-7. bekk og 8.-10. bekk. Yfir fimmtíu myndbönd bárust í keppnina, víðs vegar að af landinu. Parna höfðu nokkrir kennarar gripið keppnina sem skólaverkefni og pví bárust allmörg myndbönd frá sumum skólum. Tveir nemendur í Brekkuskóla á Akureyri sigruðu í eldri flokki með hrollvekjandi myndbandi um Vetrarfrí Hildar Knútsdóttur, en í yngri flokki sigruðu stúlkur í Ingunnarskóla í Reykjavík, sem völdu bókina Gummi og huldufólkið eftir Dagbjörtu Ásgeirsdóttur (Verðlaun veitt í Siljunni, 2016).

Siljan var haldin með sama sniði upp frá pessu og var pátttaka jöfn næstu árin, 50-60 myndbönd bárust í hverja keppni. Árið 2017 sigruðu nemendur í 5. bekk Bláskógaskóla í Reykholti í yngri flokki en allir nemendur árgangsins unnu saman að myndbandi um bókina Rúnar góði eftir Hönnu Borg Jónsdóttur. Myndbandsgerðin var liður í pemavinnu árgangsins um Barnasáttmála Sameinuðu pjóðanna (Bláskógaskóli fékk viðurkenningu fyrir myndband, 2017). Detta ár voru sigurhóparnir fjölmennir, myndband Bláskógaskóla gerði blandaður 11 barna hópur, en sigurmyndbandið í eldri flokki var unnið af átta stúlkna hópi úr 8. bekk Vogaskóla í Reykjavík, sem bjó til bráðfyndið myndband um Mömmu klikk eftir Gunnar Helgason (KrakkaRÚV, 2017).

Árið 2018 sigruðu prjár stúlkur úr Kelduskóla í Reykjavík með tilfinningaríku myndbandi um bókina Vertu ósýnilegur - flóttasaga Ishmaels eftir Kristínu Helgu Gunnarsdóttur. Í yngri flokki sigruðu prjár stúlkur úr Seljaskóla í Reykjavík sem unnu með bókina Skóladraugurinn eftir Ingu Mekkin Beck. Dröfn Vilhjálmsdóttir skólasafnskennari í Seljaskóla gerði skemmtilegt myndband um komu bókakassans á skólasafnið sem sjá má hér: https://www.facebook.com/watch/?v=1955274941451326 Sigurvegararnir úr Seljaskóla voru síđan í forsíðuviðtali í Barnablaði Morgunblaðsins, 17. júní 2018 (Unnu bækur fyrir hundrað púsund krónur, 2018). Hefðu pátttökuverðlaun verið veitt petta árið hefðu pau runnið til Vallaskóla á Selfossi en par tók leiklistarkennari keppnina upp á sína arma. Árangurinn varð sá að nemendur skólans urðu í priðja sæti í báðum flokkum (Vallaskóli, e.d.).

Árið 2019 gekk Borgarbókasafnið í Reykjavík til liðs við Barnabókasetur við framkvæmd keppninnar. Nú var aftur komið að Brekkuskóla á Akureyri að fylla hillur skólasafnsins en í eldri flokki sigraði fimm manna blandaður Brekkuskólahópur með hádramatískri stiklu um spennutryllinn Rotturnar eftir Ragnheiði Eyjólfsdóttur. Í yngri flokki sigraði átta manna blandaður hópur úr Laugarnesskóla í Reykjavík sem gerði spennandi stuttmynd með flottum tæknibrellum um Handbók fyrir ofurhetjur eftir Elias og Agnes Våhlund. Pegar hér var komið sögu var Mennta- og menningarmálaráðuneytið orðið styrktaraðili keppninnar.

Árið 2020 fór keppnin hreinlega í kófið, skólastarf var í uppnámi og heimaskólarnir með sínum samkomutakmörkunum reyndust ekki rétti vettvangurinn prátt fyrir smellið slagorð: Lestur er líka smitandi (Barnabókasetur, 2020). Pá setti strik í reikninginn að bókaútgefendur drógu sig í hlé vegna óvissu um stöðuna. Á endanum var keppnin slegin af pað árið.

Strax í upphafi skólastarfs haustið 2020 var Barnabókasetur farið að fá fyrirspurnir frá kennurum um hvort af Siljunni yrði skólaárið 2020-2021. Pegar nýr styrkur fékkst frá Mennta- og menningarmálaráðuneytinu sem tryggði að skólasafnaverðlaunin gætu haldist óbreytt prátt fyrir að útgefendur sætu hjá var ákveðið að drífa verkefnið af stað. Ýmislegt varð pó fyrir barðinu á niðurskurðarhnífnum, veggspjöld voru til dæmis ekki prentuð en pess í stað reynt að ná til kennara á samfélagsmiðlum, fyrst og fremst í kennarasamfélögum á Facebook eins og Félagi fagfólks á skólasöfnum, Skólaumbótaspjallinu, Samtökum móðurmálskennara og Upplýsingatækni í skólastarfi. Umgjörð keppninnar var jafnframt gerð algjörlega rafræn og Bókatíðindi tengd við vefsíðu Barnabókaseturs til að auðvelda börnum að kynna sér bókaútgáfuna og velja sér bækur. Um leið var búin til rafræn innsendileið á síðunni par sem pátttakendur gátu sent inn slóð á myndband ásamt viðeigandi upplýsingum. Porri myndbandanna barst pó með sama hætti og áður, gegnum tölvupóst með milligöngu kennara. 
Keppnin 2021 var pví lágstemmdari en áður og pátttaka að sama skapi lakari. Myndböndin sem dómnefnd fékk til skoðunar voru fimmtán. Samkomutakmarkanir komu líka í veg fyrir að stórum hópum væri boðið á verðlaunaafhendingu í skólunum en sigurvegarar voru pó krýndir og virkjaðir til að velja bækur fyrir verðlaunaféð. Î yngri flokki sigruðu fimm stúlkur úr Myllubakkaskóla í Reykjanesbæ með hugmyndaríku myndbandi um bók Ævars Pórs Benediktssonar, Pín eigin saga: Piparkökuhúsið. Í eldri flokki prjár sigruðu stúlkur úr Austurbæjarskóla með fagmannlega unninni stuttmyndaútgáfu af Blokkinni á heimsenda eftir Arndísi Pórarinsdóttur og Huldu Sigrúnu Bjarnadóttur.

Sigurmyndbönd Siljunnar ásamt umsögnum dómnefnda má finna á vef Barnabókaseturs (www. barnabokasetur.is) og á Facebook-síðu setursins. Par að auki eru eldri myndbönd keppninnar á Youtube, flokkuð sem „Siljan myndbönd“. Eftir gildistöku nýrra persónuverndarlaga (nr. 90/2018) var hins vegar ekki gert ráð fyrir að nemendur vistuðu myndbönd sín á opnum samfélagsrásum.

\section{Gagnasafnið: Myndbandasafn Siljunnar}

Myndböndin sem skilað hefur verið inn í Siljuna eru 230 talsins. Barnabókasetur hefur frá upphafi varðveitt upplýsingar um innsend myndbönd; kyn höfunda (ályktað út frá nöfnum), bekki, skóla og bókarval.

Að baki pessum 230 myndböndum standa hátt í 800 nemendur. Skráðir pátttakendur eru 728, par af 434 stúlkur og 294 drengir. Auk pess eru tveir heilir bekkir skráðir höfundar svo áætla má að pátttakendur séu um 760-770.

Langflest myndbandanna eru unnin af hópum, eða 210 myndbönd, en 20 eru einstaklingsmyndbönd. Pegar nánar er rýnt í kynjaskiptinguna kemur í ljós að 106 myndbönd eru eingöngu unnin af stúlkum, einum eða í hreinum stúlknahópum, 78 eru eingöngu unnin af drengjum, einum eða í hreinum drengjahópum, og 46 eru unnin af blönduðum hópum. Meðal blönduðu hópanna eru fyrrnefndir tveir bekkir par sem kennarar skráðu bekkinn sinn til pátttöku án pess að nafngreina nemendurna.

Siljan er opin nemendum í 5.-10. bekk en að fyrsta árinu undanskildu hefur verið keppt í tveimur flokkum, miðstigi grunnskóla eða 5.-7. bekk og elsta stigi grunnskóla eða 8.-10. bekk. Pegar öllum myndböndunum 230 er skipt eftir pessum meginlínum kemur í ljós að 47 peirra eru unnin af nemendum á eldra stiginu eða í 8.-10. bekk en 181 af nemendum á yngra stigi eða í 5.-7. bekk. Auk pess er eitt myndband unnið af blönduðum hópi 5.-8. bekkinga og eitt unnu nemendur úr 7. og 10. bekk saman.

Myndböndin 230 fjalla um 117 bækur, sumar bækur koma fyrir í einu eða tveimur myndböndum en sú vinsælasta í 16 myndböndum. Af pessum 117 bókum eru 27 skilgreindar sem ungmennabækur samkvæmt bókaútgefendum, tíu eru skilgreindar sem myndabækur og fjórar sem fræðibækur fyrir börn. Hinar 76 eru „hefðbundnar barnabækur“ eða skáldverk fyrir um pað bil 6-12 ára lesendur.

Sá höfundur sem nýtur mestra vinsælda Siljukeppenda er Gunnar Helgason. Alls eru 36 myndbönd í safninu um sex bækur eftir Gunnar, vinsælust bóka hans er Mamma klikk en 16 myndbönd eru um hana. Sex myndbönd eru um Ömmu best, fimm um Pabba prófessor og prjú um Sigga sitrónu. Pá eru 6 myndbönd um fótboltabækur Gunnars, par af fimm um Gula spjaldið i Gautaborg.

Næstur í vinsældaröðinni er Ævar Pór Benediktsson en í safninu eru 30 myndbönd um átta bækur eftir hann. Af peim eru 27 myndbönd um bækur í Pin eigin bókaflokknum, par af eitt um léttlestrarútgáfuna Pitt eigið piparkökuhuis. Prjú myndbönd eru um bók í flokknum Bernskubrek Ævvars visindamanns.

Priðji í röðinni er David Walliams en 17 myndbönd eru í safninu um átta bækur eftir hann. Pessir prír höfundar tengjast pví samanlagt 83 myndböndum af 230 í safninu, eða 36\%. 
Pessir prír höfundar eiga einnig flesta bókartitla. Í safninu eru myndbönd við átta bækur eftir Ævar Pór Benediktsson, átta bækur eftir David Walliams og sex bækur eftir Gunnar Helgason.

Næstir á listanum eru Porgrímur Práinsson og Jeff Kinney sem tengjast níu myndböndum hvor. Sjö af myndböndunum um bækur Porgríms eru um Henri bókaflokkinn. Myndböndin um bækur Jeff Kinney eru um fimm titla í bókaflokknum um Kidda klaufa.

Átta myndbönd eru um fjóra titla í ráðgátubókaflokki Martins Widmark og Helenu Willis. Helena Willis er par með sú kona sem oftast kemur fyrir á höfundalistanum. Hildur Knútsdóttir er höfundur bóka í sex myndböndum, prjú af peim eru um hrollvekjuna Vetrarfrí og eitt um framhaldsbókina Vetrarhörkur.

Fimm myndbönd eru um bækur í flokknum Leyndarmál Lindu eftir Rachel Renée Russell. Einnig eru fimm myndbönd um bókaflokkinn Orra óstöðvandi eftir Bjarna Fritzson.

Fjögur myndbönd eru um bókina Skóladraugurinn eftir Ingu Mekkin Beck. Pá eru prjú myndbönd um Leitina að tilgangi unglingsins eftir Bryndísi Björgvinsdóttur, Óla Gunnar Gunnarsson og Arnór Björnsson, og prjú myndbönd um prjár Skúla skelfis bækur eftir Francescu Simon. Aðrir höfundar og titlar koma sjaldnar fyrir.

\section{Bókaval í Siljunni, bóksala og skólasöfn}

Pátttakendur í Siljunni velja sér sjálfir bækur til að skapa út frá. Gera má ráð fyrir að bókavalið endurspegli bókmenntasmekk barna og unglinga og ekki síður vinsældir ákveðinna bóka í barnasamfélaginu. Pað er pví áhugavert er að bera saman bókaval pátttakenda í Siljunni og metsölulista barna- og ungmennabóka annars vegar og útlánatölur skólasafnanna hins vegar.

Félag íslenskra bókaútgefenda tekur saman árslista bóksölu og birtir á vefsíðu sinni fibut.is. Árslistarnir eru greindir eftir bókmenntategundum; barnabækur, ungmennabækur, skáldverk, ljóð o.s.frv.. Par sem engar sölutölur fylgja árslistunum er erfitt að bera saman sölu barnabóka annars vegar og ungmennabóka hins vegar og pví er hér miðað við barna- og ungmennabækur sem ná inn á heildarlistann yfir söluhæstu titla landsins.

Siljan hófst vorið 2015 og pátttakendur gátu valið bækur sem komu út næstliðin prjú ár. Pað ár voru bækur frá 2012-2014 í boði, í Siljunni 2016 voru pað bækur útgefnar 2013-2015 o.s.frv. Elstu bækurnar í myndbandasafni Siljunnar komu pví út 2012. Elstu metsölulistarnir á vefsíðu Félags bókaútgefenda eru hins vegar fyrir árið 2013. Ófullkomnar upplýsingar liggja fyrir varðandi árið 2012 en benda pó til pess að Aukaspyrna á Akureyri eftir Gunnar Helgason hafi verið söluhæsta barnabók ársins og sú eina sem náði inn á heildarlistann, auk Heimilisréttabókar Disney (upplýsingar fengnar með tölvupósti).

Árið 2013 var Visindabók Villa eftir Vilhelm Anton Jónsson söluhæsta barna- eða ungmennabókin (í 3. sæti á heildarlistanum) en Rangsteður i Reykjavik eftir Gunnar Helgason var í öðru sæti (í 9. sæti á heildarlistanum) (Félag íslenskra bókaútgefenda, 2013).

Árið 2014 var Gula spjaldið i Gautaborg eftir Gunnar Helgason í efsta sæti (4. sæti á heildarlistanum) og Pin eigin pjóðsaga eftir Ævar Pór Benediktsson í öðru sæti (6. sæti á heildarlistanum) (Félag íslenskra bókaútgefenda 2014a).

Söluhæsta barna- eða ungmennabókin 2015 var Mamma klikk eftir Gunnar Helgason (3. sæti á heildarlistanum) en Pin eigin goðsaga eftir Ævar Pór Benediktsson var í öðru sæti (í 5. sæti á heildarlistanum) (Félag íslenskra bókaútgefenda, 2015).

Árið 2016 seldist Pabbi prófessor eftir Gunnar Helgason mest allra barna- og ungmennabóka (í 3. sæti á heildarlistanum) en í öðru sæti var Pin eigin hrollvekja eftir Ævar Pór Benediktsson (í 5. sæti á heildarlistanum) (Félag íslenskra bókaútgefenda, 2016). 
Árið 2017 var Amma best eftir Gunnar Helgason söluhæsta barna- eða ungmennabókin (í 3. sæti á heildarlistanum) en Fitt eigið avintýri eftir Ævar Pór Benediktsson var í öðru sæti (í 4. sæti á heildarlistanum) (Félag íslenskra bókaútgefenda, 2017).

Siggi sitróna eftir Gunnar Helgason var mest selda barna- og ungmennabókin 2018 (í 5. sæti á heildarlistanum) en Pitt eigið tímaferðalag Ævars Pórs Benediktssonar var í öðru sæti (í 7. sæti á heildarlistanum). Í priðja sæti var fyrsta bókin um Orra óstöðvandi eftir Bjarna Fritzson (í 12. sæti á heildarlistanum) (Félag íslenskra bókaútgefenda, 2018).

Árið 2019 seldist Pinn eigin tölvuleikur eftir Ævar Pór Benediktsson best (í 4. sæti á heildarlistanum) en Orri óstöðvandi - hefnd glaponanna eftir Bjarna Fritzson var í öðru sæti (6. sæti á heildarlistanum) (Félag íslenskra bókaútgefenda, 2019).

Bjarni Fritzson náði efsta sætinu 2020 en Orri óstöðvandi - Bókin hennar Möggu Messi seldist mest allra barna- og ungmennabóka (í fimmta sæti á heildarlistanum). Pín eigin undirdjúp eftir Ævar Pór Benediktsson var í priðja sæti (10. sæti á heildarlistanum) á eftir Syngdu með Láru og Ljónsa eftir Birgittu Haukdal (Félag íslenskra bókaútgefenda, 2020).

Bókaval pátttakenda í Siljunni endurspeglar að verulegu leyti sölulistana. Eins og rakið er hér hafa Gunnar Helgason og Ævar Pór Benediktsson löngum setið í efstu sætum listanna. Gunnar var í fyrsta sæti en Ævar Pór í öðru sæti öll árin 2014-2018, Gunnar var auk pess í fyrsta sæti 2012 og í öðru sæti 2013 og Ævar Pór í fyrsta sæti 2019. Pað kemur pví ekki á óvart að peir tveir skuli njóta mestra vinsælda í Siljunni en Gunnar og Ævar Pór eru höfundar bókanna í 66 myndböndum eða $27 \%$ heildarinnar. Gunnar er auk pess höfundur vinsælustu bókarinnar; Mömmu klikk.

Síðustu ár hefur Bjarni Fritzson notið vaxandi vinsælda, samkvæmt metsölulistum. Orri óstöðvandi nýtur líka vaxandi vinsælda í keppninni en prjú af myndböndunum fimm um Orra eru um Bókina hennar Möggu Messi sem kom út 2020. Athyglisvert er að engin myndbönd bárust um tvær nýjustu bækur Gunnars Helgasonar; Draumapjófinn (2019) og Barnareningjann (2020). Pessar tvær bækur enduðu líka mun neðar á sölulistum en fyrri bækur Gunnars; Stellu bókaflokkurinn og Fótboltasagan mikla. Ævar Pór Benediktsson hefur hins vegar haldið sínu, bæði á sölulistunum og í Siljunni.

David Walliams er vinsæll höfundur en vinsældir hans í Siljunni eru pó umfram pað sem búast mátti við út frá sölulistum. Bækur hans hafa setið í 5.-7. sæti á lista yfir mest seldu barnabækurnar en sjaldnast nád inn á heildarlistann yfir 20 söluhæstu bækur ársins. Hann er hins vegar, eins og Gunnar og Ævar Pór, mikilvirkur höfundur og ný bók kemur út eftir hann á hverju ári, stundum tvær. Lesendur hans vita að hverju peir ganga og geta alltaf fundið nýja bók að glíma við.

Útlánatölur skólasafnanna sýna talsvert aðra mynd. Leitarvél Landskerfis bókasafna sýnir að engar bækur frumsamdar á íslensku komust inn á lista yfir tíu vinsælustu ritin í bókasöfnum grunnskólanna á árunum 2013-2020, en útlánatölur fyrir 2012 eru ekki til. Syrpur virðast vera langvinsælasta efnið sem börnin taka út í skólanum par sem pær eru síðustu árin allar skráðar sem einn titill. Bókaflokkurinn um Kidda klaufa eftir Jeff Kinney er pó mun vinsælli par sem hver titill er skráđur sér. Á listanum yfir vinsælasta efnið 2020 eru Syrpur nr. 1 en Kidda klaufa bækur í sætum 2-5 og 8-10. Hundmann eftir Dav Pilkey og Handbók fyrir ofurhetjur eftir Elias og Agnes Våhlund eru í sætum 6 og 7. Árið 2019 voru Syrpurnar nr. 1 en Handbók fyrir ofurhetjur nr. 2, 4 og 8 og Kidda klaufa bækur í 3., 5.-7. og 9.-10. sæti. Árið 2018 voru Syrpurnarí 1. sæti en Kiddi klaufi í öllum öðrum sætum. Árið 2017 voru Syrpur í 1. og 9. sæti (Syrpa 2009 skrád sér), en Kiddi klaufi í öllum öðrum sætum. Fleiri Syrpur eru á eldri listum, áður en farið var að skrá pær sem einn titill. Kiddi klaufi er pó vinsælastur ásamt Syrpunum en aðrir titlar sem sjást á listum eru Kafteinn ofurbrók eftir Dav Pilkey og tímaritið Galdrastelpur W.I.T.C.H. (2013), Úkk og Glúkk eftir Dav Pilkey og Skúli skelfir eftir Fransescu Simon (2014), og Hans og Gréta (2016) (Landskerfi bókasafna, e.d.). 


\section{Kynjaskekkja og unglingavandi}

Pví er stundum haldið fram að drengir lesi minna en stúlkur pví barnabókaútgáfan sé kvenlæg, höfundar barnabóka séu mikið til konur, söguhetjurnar stúlkur og bækurnar höfði ekki til drengja (sjá t.d. Lipsyte, 2011). Yfirlitið hér að framan kveður slíkar kenningar í kútinn. Karlhöfundar ráða ríkjum á öllum premur sviðunum; í Siljunni, á metsölulistunum og á skólasöfnunum. Í norrænni úttekt á PISA-könnuninni 2009 var sjónum beint að stöðu drengja í lestri. Meðal annars var lagt til að kennarar á Norðurlöndunum legðu sig fram við að ná til drengja og að bjóða pyrfti upp á lesefni sem höfðaði til drengja (Nordic Council of Ministers, 2012). Siljan nær til útgáfuáranna 2012-2020 og myndbandasafn hennar svarar pví að einhverju leyti hvort pær bækur sem skólabörn hafa aðgang að hérlendis eru „drengjavænar“. Útlánatölur skólafnanna svara pví pó enn betur. Einu kvenkyns söguhetjurnar á topp-tíu útlánalistum skólasafnanna sl. átta ár eru Galdrastelpurnar og Gréta, auk Andrésínu, ömmu andar og örfárra annarra kvenkyns íbúa Andabæjar. Reyndar má efast um að Gréta eigi heima á listanum, skráning peirrar bókar stingur í stúf, pannig er útgáfuárið 1900 og öll útlán hennar skráð á skólasöfnin á Suðurlandi/Suðurnesjum par sem hún er næstum prefalt vinsælli en Syrpur eða Kiddi klaufi. Næsta bók inn á listann í pessum landshluta er enn ein Kidda klaufa bókin svo heildarmyndin væri óbreytt pótt Hans og Gréta væru tekin út. Einu kvenhöfundarnir á lista skólasafnanna eru Fransesca Simon, höfundur Skúla skelfis, sem krækti í 10. sætið 2014 og myndhöfundurinn Agnes Våhlund sem skapar Handbók fyrir ofurhetjur ásamt manni sínum, Eliasi Våhlund, en bækur úr flokki peirra komust á listana 2019 og 2020.

Fyrirfram var búist við ákveðinni kynjaskekkju í Siljunni. Reiknað var með að stúlkur tækju frekar pátt en drengir í lestrartengdu verkefni. Par var horft til rannsókna á lestrarvenjum kynjanna sem sýna að lestraráhugi er almennari meðal stúlkna en drengja og að sama skapi eru pær jákvæðari í garð lestrar (Brynhildur Pórarinsdóttir o.fl., 2012, 2017; Hafdís Guðrún Hilmarsdóttir o.fl., 2018; Logan og Johnston, 2009). Pað kom pví ekki á óvart að stúlkur skyldu vera í meirihluta í hópi pátttakenda í Siljunni. Hlutfall kynjanna er pó enn ójafnara en búast mátti við. Næstum helmingur myndbandanna er unninn af stúlkum, einum eða í hreinum stúlknahópum, priðjungur af drengjum. Athygli vekur hversu lítið kynin vinna saman en aðeins eitt af hverjum fimm myndböndum er unnið af kynjablönduðum hópi. Рað segir pó líklega mest um eðli vináttu á grunnskólaaldri og hvernig börn velja sér félaga.

Pær bækur sem oftast koma við sögu í Siljunni eiga pað allar sameiginlegt að vera seríubækur. Börn sækja í að hitta vini sína á síðum bóka, ekki síður en í raunveruleikanum. Listinn yfir vinsælustu bækurnar inniheldur Pin eigin bækur Ævars Pórs Benediktssonar og Bernskubrek Ævvars vísindamanns, Fótboltasöguna miklu og Stellubakur Gunnars Helgasonar, Henri-bakur Porgríms Práinssonar, sænsku Rádgátuseriuna og pekkta kappa á borð við Kidda klaufa, Orra óstöðvandi og Skúla skelfi. Bækur David Walliams eru ekki seríubækur en keimlíkar í útliti, stíl og jafnvel efni pannig að lesendur vita að hverju peir ganga. Myndir Quentin Blake eiga ríkan pátt í að skapa pá seríu-ímynd sem bækurnar hafa. Langvinsælasta efnið á skólasöfnum landsins er líka í seríuflokknum; Syrpur og Dagbakur Kidda klaufa. Annað efni sem kemst á útlánalista skólasafnanna er að sama skapi úr seríum. Allt er petta ríkulega myndskreytt efni og jafnvel í teiknimyndasagnastíl að hluta til eða öllu leyti.

Pegar litið er til pess að pað eru fyrst og fremst seríubækur sem börnin leita í má velta fyrir sér hvers vegna minna beri á konum en körlum í slíkri útgáfu á Íslandi. Bækurnar um Leyndarmál Lindu eftir Rachel Renée Russell og Rádgátubakurnar sem Helena Willis er annar tveggja höfunda að eru vinsælasta framlag kvenna í Siljunni. Af íslenskum höfundum er pað Hildur Knútsdóttir, en nemendur völdu Vetrarfrí, Vetrarhörkur, Ljónið og Doddi - ekkert rugl sem Hildur skrifaði með Dórdísi Gísladóttur. Allar pessar bækur eiga sér framhald eða forsögu.

Athygli vekur hversu fáar ungmennabækur hafa verið teknar fyrir í Siljunni. Einungis 27 af bókunum 117 eru flokkaðar sem ungmennabækur skv. útgefendum. Lakari pátttaka unglinga skýrir petta að einhverju leyti en einungis 47 myndbönd af 230 eru unnin af nemendum í 8.-10. bekk. Fyrirfram var búist við minni pátttöku eldri hópsins par sem vitað er að áhugi barna á lestri minnkar með aldrinum. Nemendur í 5.-7. bekk væru pví líklegri en unglingar til að vilja vinna lestrartengt verkefni. 
Munurinn er hins vegar mikill, um átta af hverjum tíu myndböndum eru eftir miðstigsnemendur en einungis tvö af hverjum tíu eftir unglinga.

Lakari pátttaka unglinga getur átt sér skýringar í skipulagi skólastarfs pví langflest myndbönd Siljunnar hafa orðið til sem skólaverkefni. Víðast er kennsla á unglingastigi komin í hendur sérgreinakennara og minna svigrúm fyrir verkefni á borð við petta ef ekki er gert ráð fyrir pví við undirbúning annarinnar. Yndislestur er ef til vill á dagskrá en ekki gert ráð fyrir að hann fái pann tíma sem parf til að vinna skapandi verkefni í framhaldinu.

Fáir ungmennabókatitlar og slök pátttaka unglinga er pó líklega fyrst og fremst til marks um pað tómarúm sem lesendur á unglingsaldri eru í. Bókaútgefendur kynntu flokkinn ungmennabækur í Bókatíðindum 2014 (Félag íslenskra bókaútgefenda, 2014b) og fylgdu par eftir vaxandi áhuga erlendis á pví sem kallað er YA eða young adult literature. YA-bækur eru markaðssettar fyrir 13 ára og eldri en í raun lesnar af fólki fram eftir aldri og pví er petta býsna teygjanleg flokkun. Fram að pessu höfðu bækur fyrir ungmenni leynst í flokknum barna- og unglingabækur í Bókatiððindum. Pegar ungmennabækur voru dregnar út með pessum hætti blasti við hversu fáar bækur eru gefnar út fyrir ungmenni samanborið við hvort sem er yngri börn eða fullorðna lesendur. Árið 2014 voru sex íslenskar bækur flokkaðar sem ungmennabækur og tólf pýddar. Heildarfjöldinn hélst svipaður öll Siljuárin, en í Bókatíðindum 2020 eru kynntar 19 ungmennabækur. Pegar betur er að gád eru tvær af pessum 19 Storytel-útgáfur eldri verka, tvær eru endurútgáfur af Harry Potter og ein endurútgáfa af uppseldri ungmennabók frá 2015. Nýjar íslenskar ungmennabækur eru átta, pýddar ungmennabækur, misnýjar pó, eru sex.

Petta takmarkaða úrval ungmennabóka á væntanlega sinn pátt í óvæntu bókavali unglinga í keppninni. Af peim 47 myndböndum sem skráð eru á nemendur í 8.-10. bekk eru tólf um bækur sem augljóslega eru ætlaðar yngri lesendum, ríkulega myndskreyttar bækur og léttlestrarbækur. Á bókalista Siljunnar eru tíu myndabækur sem markaðssettar eru fyrir leikskólaaldurinn, flestar valdar af eldri hópnum. Unglingarnir nálgast myndabækurnar gjarnan með húmor og hálfkæringi, eins og myndbönd 10. bekkinga um Hvolpasveit og köflótta fílinn Elmar bera vott um, og síðast en ekki síst sigurmyndbandið um Brosbókina frá 2015 sem unnið var af nemendum í 7. og 10. bekk. Unglingsstúlkurnar sem gerðu myndband um léttlestrarbókina Svarta kisa fer i bað sýndu hugmyndaauðgi með pví að ráða kolsvartan lifandi kött í aðalhlutverkið. Pær sem gerðu myndband um bókina Lára fer til laknis beittu húmor, búningum og klippingum til að minna á umræðurnar sem urðu um úrelta staðalmynd hjúkrunarkonu (svo!) í bókinni.

Рað má segja að unglingarnir í keppninni fari tvær leiðir að markinu, annaðhvort velja peir ungmennabækur, draga fram dramatík og spila á tilfinningar áhorfenda með myndmáli, hljóðmynd og tónlist, eða peir taka léttar bækur miðað við aldur og nálgast pær af kímni og kaldhæðni.

\section{Lærdómurinn af Siljunni}

Myndbandasafn Siljunnar gefur innsýn í hugarheim barna og unglinga á mið- og unglingastigi grunnskóla. Segja má að báðir hóparnir standi á lestrarlegum tímamótum. Á miðstigi er formlegri lestrarkennslu víðast lokið en krefjandi lesefni á sama tíma að aukast. Viðhorf og venjur gagnvart lestri eru að mótast; sumir nemendur mynda vináttusamband við bækur en aðrir forðast pær eins og heitan eldinn. Bilið milli pessara hópa heldur áfram að breikka upp eftir grunnskólanum. Á unglingastigi er orðinn umtalsverður munur milli peirra sem iðka lestur og hinna sem aldrei lesa sér til ánægju. Munur á lesskilningi pessara hópa hefur reynst samsvara um einu og hálfu skólaári (OECD, 2011). Nemendur í eldri hópnum hafa pví tamið sér venjur eða ósiði (!) í lestri sem fylgja munu peim upp í framhaldsskóla par sem peir purfa að takast á við bæði pyngra og viðameira lesefni.

Talsverður kynjamunur birtist í myndbandsafni Siljunnar sem endurómar pann mikla kynjamun sem rannsóknir á lestri grunnskólanemenda bæði á mið- og unglingastigi hafa leitt í ljós. Pannig mælist kynjamunur í lestrarvenjum og árangri í lesskilningi meðal 10. bekkinga stúlkum í hag (Brynhildur 
Pórarinsdóttir o.fl., 2012, 2017; Menntamálastofnun, 2019), sem og í lestrarvenjum og viðhorfum til lestrar í 5. og 6. bekk. Stúlkur í 5. og 6. bekk hafa almennt meiri lestraráhuga en drengir, en lestrarfælni er algengari meðal drengja (Hafdís Guðrún Hilmarsdóttir o.fl., 2018). Kynjamunurinn í Siljunni kemur fram í pví að mun færri drengir hafa tekið pátt en stúlkur og langflestir peirra fyrir tilstilli kennara. Drengir virðast pví purfa meiri og beinni hvatningu til að hella sér í lestrartengd verkefni en stúlkur. Pennan mun á framtakssemi kynjanna í keppninni er nærtækast að skýra með mismunandi lestraráhuga og lestrarvenjum kynjanna, en mætti pó allt eins skoða út frá rannsóknum á virkni í skólastarfi. Stúlkur eru almennt virkari í skólastarfinu en drengir og pessi munur á virkni kynjanna er jafnvel talinn geta skýrt kynjamun í lesskilningi (Sigrún Jónatansdóttir o.fl., 2017).

Siljuna má skoða sem áminningu um hversu mikilvægt er að vinna með viðhorf til lestrar í skólanum. Margir nemendur purfa hjálp við að yfirstíga neikvæðar tilfinningar í garð lestrar, jafnvel lestrarfælni. Drengir eru fjölmennari í pessum hópi en stúlkur. Pessi neikvæðni í garð lestrar kann að eiga sér samfélagslegar skýringar en opinber orðræða um lestur grunnskólanemenda, einkum drengja, hefur verið afar neikvæð síðustu árin. Orðræðan um drengi sem lesa sér ekki til gagns hefur síast inn í skólana og haft áhrif á sjálfsmynd drengja sem lesenda, eins og fram kom í ÍNOK-rannsókninni (Brynhildur Pórarinsdóttir og Kristján Jóhann Jónsson, 2018). Pegar lestrartengd verkefni eru lögð fyrir í skólanum er pví nauðsynlegt að átta sig á hversu ólíka hvatningu og nálgun nemendur purfa. Staðalmyndir og sjálfsmynd hafa áhrif á löngun og drifkraft nemenda til að opna bók og sumir purfa verulegan stuðning til að yfirvinna sálfélagslegu hindranirnar.

Pegar rýnt er í sögu Siljunnar kemur í ljós að pátttaka nemenda í verkefninu er tengd áhuga kennara en pátttaka hefur verið mest í skólum par sem kennarar hafa tekið keppnina upp á sína arma. Kennarar hafa pá notað Siljuna sem skólaverkefni og séð um að senda myndböndin inn. Í pessum tilvikum hafa allir nemendur verið virkjaðir til lestrartengdrar vinnu og vel að merkja - pá hallar ekki á drengina. Peirra myndbönd eru unnin af innlifun, sköpunarkrafti og hugmyndaauðgi ekki síður en myndbönd stúlknanna. Skapandi hópvinna í tengslum við lestur virðist pví höfða til drengja, ekki siðður en stúlkna. Рað er í samræmi við niðurstöður Soffíu Vagnsdóttur (2021) um áhuga nemenda á skapandi verkefnum og hópvinnu.

Pað má pví ekki vanmeta pátt kennarans í að virkja nemendur og skapa stemningu fyrir lestri innan bekkjarins. Segja má að hlutverk kennarans sem áróðursmeistara lestrar sé sérstaklega mikilvægt eftir að lestrarkennslu lýkur. Nemendur á mið- og unglingastigi purfa ekki aðeins aðgang að áhugaverðu lesefni, heldur parf bókstaflega að halda pví að peim. Siljan sýnir hversu miklu máli skiptir að kennari sé áhugasamur og hversu virkir nemendahópar geta verið í lestrartengdum verkefnum, fái peir hvatningu og tíma til að vinna pau. Nemendur kalla eftir meira vali, skapandi viðfangsefnum og auknu samvinnunámi, eins og fram kom í rannsókn Soffíu Vagnsdóttur (2021). Unnt er að gera miklu meira af slíku pegar kemur að lestrinum. Áhersla á samvinnunám í bókmenntum væri í anda aðalnámskrár par sem línur eru lagðar um að líta beri á læsi frá félagslegum sjónarhóli; að sköpun merkingar verði ekki til í tómarúmi heldur ráðist af reynslu lesandans og aðstæðum (Mennta- og menningarmálaráðuneyti, 2013). Nemendur sem vinna skapandi hópverkefni í bókmenntum læra að hlusta á og virða skoðanir annarra, peir venjast pví að allir geti lagt eitthvað til málanna og að sjónarhornin geti verið mörg og ólík. Við slíka verkefnavinnu gegnir fjölbreytt bókaútgáfa lykilhlutverki; sumir hlusta á bókina en aðrir lesa hana af pappír eða skjá. Pannig geta hæglæsir nemendur og fluglæsir unnið saman og lært hverjir af öðrum.

Рað er engin nýjung í skólastarfi að setja nemendum fyrir að búa til bókamyndbönd. Pað er víða gert í bókmenntakennslu en að pví er virðist fyrst og fremst pegar unnið er með eldri bókmenntir. Á Youtube má t.d. finna fjölda myndbanda um Laxdælu eftir grunnskólanemendur. Skólasamfélagið viðurkennir pví að brúa purfi bilið milli fornra bókmennta og menningarheims barna og beita tæknilegum leiðum til að virkja áhugahvötina. Рað virðist sjaldgæfara að nemendur fái að endurskapa pað sem kallað hefur verið yndislestrarbækur; barna- og ungmennabækur sem börnin velja sér sjálf til ánægju. Petta hefur hins vegar verið lykilatriðið í Siljunni. Bókaval Siljunnar bendir til pess að tískustraumar séu sterkir í barnaheiminum og í samræmi við metsölulista sem aftur endurspegla 
markaðssetningu. Búast hefði mátt við pví að bókaval í Siljunni, metsölulistar og útlánatölur skólasafna hefðu svipaða sögu að segja en skólasöfnin eru sér á parti. Einsleitir útlánalistar skólasafnanna 2013-2020 vekja ýmsar spurningar. Mikilvægt er að nemendur fái að velja lesefni en peir purfa aðstoð við að átta sig á breiddinni í útgáfunni og tækifæri til að kynnast fjölbreyttu efni. Aðgengi barna að alls konar bókum er lykilatriði fyrir uppbyggingu lestraráhuga. Skólasöfnin purfa að eiga spennandi bókakost, sýna hann og kynna, og bækur fyrir viðkomandi aldur purfa að tilheyra daglegu skólastarfi í kennslustofum. Pví miður sýndi ÍNOK-rannsóknin að barna- og ungmennabækur væru sjaldan sýnilegar í skólastofum á mið- og unglingastigi (Brynhildur Pórarinsdóttir og Kristján Jóhann Jónsson, 2018).

Nemendur purfa að fá tækifæri til að verða peir proskuðu lesendur sem aðalnámskrá ætlast til að útskrifist úr grunnskóla; sjálfstæðir lesendur sem geta valið sér lesefni. Peir purfa að kynnast margbreytilegum bókmenntum til að finna hvar lestraráhugi peirra liggur og pjálfun í að kafa ofan í pær. Myndböndin í Siljunni sýna hversu djúpt nemendur geta kafað í bókmenntir ef peir vinna með efni sem vekur áhuga peirra, sérstaklega pegar peir fá að vinna saman og hver og einn getur lagt sitt af mörkum eftir reynslu og áhugasviði. Um leið er bókaval unga kvikmyndagerðarfólksins áminning um hversu myndrænn menningarheimur barna er. Vinsælustu höfundarnir í Siljunni eru leikarar sem einnig hafa unnið við gerð barnaefnis fyrir aðra miðla; sjónvarp, útvarp, leikhús og kvikmyndir. Peir sem vinna að lestrarhvatningu purfa að hafa opinn huga gagnvart annars konar menningarefni, hætta að óttast samkeppni við bókina og fara að nýta tæknina og miðlana í págu lestrar. Kristján Jóhann Jónsson (2013) orðaði pað svo að bókmenntir og lestur gætu ekki og ættu ekki að keppa við afpreyingarmiðla á borð við spennumyndir og tölvuleiki. Kennarar yrðu hins vegar að pekkja pessa miðla yngri kynslóðarinnar, kunna að tengja veigamikla bókmenntatexta við pá og „pýða á milli“ miðla.

\section{Jákvæð nálgun gegn lestrarleiða}

Neikvæðni í garð lestrar, lestrarfælni og orðalagið „leiðinleg skólaverkefni“ benda til pess að hópur nemenda finni enga ánægju af lestri heldur pvert á móti leiðist peim. Skólaleiði getur brotist fram sem áhugaleysi og skortur á framtakssemi. Nemendur nefna gjarnan einsleitni og endurtekningar í kennslu og tilgangsleysi verkefna sem ástæðu pess að peim leiðist í skólanum (Daschmann o.fl., 2014). Ef litið er á lestrarleiðann frá pessu sjónarhorni má spyrja hvort pær aðferðir sem beitt hefur verið við að halda lestri að börnum hafi snúist upp í andhverfu sína. Jafnframt má velta fyrir sér hvort nemendur sjái tilgang í peim lestrartengdu verkefnum sem skólinn setur fyrir og hvort pau séu nægilega fjölbreytt.

Siljan er engin töfralausn gegn lestrarleiða en hún er amboð í verkfærakassa lestrarhvetjandi kennara. Keppnin byggir á hugmyndafræði um jákvæða nálgun gegn „lestrarvandanum“ margumrædda. Við mótun keppninnar var stuðst við rannsóknir á lestrarvenjum og lesskilningi, samspili pessa og áhrifapáttum. Niðurstöður peirra gáfu tilefni til að ætla að vænlegt væri að efla lestur gegnum áhugasvið barnanna og félagslíf; pað er að virkja áhugahvöt og tengja lestur við gleði og samveru. Með skapandi verkefnum á borð við Siljuna getur lesturinn orðið að spennandi tölvuverkefni sem vinna má með vinum sínum, utandyra sem innan, með ærslum og gleði. Par með er unnið gegn peirri goðsögn að bækur og tækni séu andstæðir pólar í tilveru barna; að annaðhvort lesi börn bækur eða hangi í tölvunni. Börnin fá tækifæri til að túlka og tjá sig um bókmenntir með aðstoð nútímatækni og beita öllum peim möguleikum sem tækin bjóða upp á til að dýpka skilning sinn og koma honum til skila. Nemendur purfa að vera hugmyndaríkir og lausnamiðaðir og nýta sér færni í margvíslegum námsgreinum. Рað sýndu til dæmis fimmtubekkingar í Rimaskóla sem bjuggu til æðislegar grímur til að bregða sér í hlutverk söguhetja úr Hundmann eftir Dav Pilkey, eins og sjá má hér: http://youtu. be/hzrWyisuHX8. Metnaður og sköpunargleði tryggði peim priðja sætið í yngri flokki 2021. Sigurvegararnir í báðum flokkum 2021 notuðu leikmuni og gervi af hugvitssemi til að draga fram ólíkar persónur og sjónarhorn. Pessi myndbönd sýna næmt auga fyrir frásagnartækni kvikmyndalistarinnar; eldri flokkur: https://youtu.be/Qa-0xTvahB4 og yngri flokkur: https://youtu.be/QdaR5ycASNA. 
Drengirnir í 7. bekk Myllubakkaskóla sem bjuggu til hasarstiklu um Henri rant i Rússlandi eftir Porgrím Práinsson notuðu texta og tónlist í stað tals og beittu tæknibrellum og hasar, sjá https://www. youtube.com/watch?v=ejd VxA435Q. Skapandi verkefni geta pví gefið nemendum færi á að túlka sögur af innlifun, hversu færir sem peir eru í tungumálinu.

Pegar rætt er um sköpun í skólastarfi er gott að hafa í huga að hugtakið sköpun nær ekki eingöngu yfir listræn verkefnaskil. Nemendur skapa merkingu með pví að skilja og túlka textann sem peir lesa. Kristján Jóhann Jónsson (2013) telur að kennsla í bókmenntum og lestri eigi að vera „kennsla í pví að túlka texta og veruleika, með öðrum orðum skapandi og gagnrýnin vinna“. Pegar myndbönd Siljunnar eru skoðuð sést hvernig bókmenntir og myndmiðill vinna saman að pessu leyti. Börnin kryfja börnin bókina pegar pau skrifa handrit og skipuleggja tökur. Pau ræða um bókmenntafræðileg hugtök á borð við persónur og sjónarhorn, sem erfitt hefur pótt að kenna, eins og fram kom í ÍNOK-rannsókninni. Par höfðu sumir kennarar einmitt notað kvikmyndir eða eigin ritun nemenda til að kenna bókmenntafræðileg hugtök. Hugsanlega má komast enn lengra með pví að tvinna petta saman og tengja hugtök við eigin kvikmyndagerð nemenda. Börnin koma djúpri túlkun á framfæri með tónlist, svipbrigðum, sviðsetningum, klippingum og búningum; mögulega dýpri og innilegri en pau hefðu náð að sýna með ritgerð eða öðrum hefðbundnum leiðum. Рað er einmitt lykilatriði fyrir dýpri lesskilning að geta dregið ályktanir og skapað merkingu; skynjað hið ósagða, lesið milli línanna og sett hlutina í samhengi við eigin pekkingu og reynslu.

Stúlkurnar í Kelduskóla sem gerðu sigurmyndbandið um bók Kristínar Helgu Gunnarsdóttur Vertu ósýnilegur - flóttasaga Ishmaels réðust ekki á garðinn par sem hann er lægstur: https://www.youtube. com/watch?v=R1R6a5HM6Ts.

Bókin fjallar um ungan pilt sem tekst á við mikinn missi pegar hann flýr styrjöldina í Sýrlandi. Stúlkurnar nota klippingar, tæknibrellur og tónlist til að skapa tilfinningaprungið andrúmsloft mannskæðrar borgarastyrjaldar á Íslandi og með pví fá pær áhorfendur til að samsama sig sýrlenska flóttadrengnum. Tifandi pögnin sem ríkti í bekknum pegar myndbandið var sýnt við verðlaunaafhendinguna staðfesti hversu djúpt pað snart unglingana. Sekúndurnar eftir að slökkt var á skjánum voru svolítið erfiðar fyrir suma. Pegar áhrifamáttur bókmennta verður svona ápreifanlegur er óhætt að viðurkenna að verkefnið hefur skilað árangri.

Markmið Siljunnar sneru að nemendum, skólunum og skólasöfnunum. Með keppninni var að stefnt að pví að efla lestraráhuga barna og unglinga, beina sjónum skólasamfélagsins að barna- og ungmennabókum og styrkja skólasöfnin. Hátt í 800 grunnskólanemendur hafa tekið pátt í Siljunni með pví að lesa bækur og skapa út frá peim. Myndbönd Siljunnar sýna gagnsemi pess að vinna með „venjulegar" barna- og unglingabækur í skólunum; hversu fær börn og unglingar eru í að kryfja og túlka bókmenntir fái pau að velja bækur og verkefni sem höfðar til peirra. Myndböndin bera vott um ánægju og innlifun og par með pá jákvæðu upplifun af bókmenntum sem er forsenda pess að nemendur lesi af eigin hvötum. Keppnin virðist pví hafa virkjað lestraráhugahvöt nemenda en svo er annað mál hvort pátttaka í einu verkefni nægi til að breyta venjum og viðhorfum til langframa. Bætt lestrarmenning parf að vera viðvarandi viðfangsefni í skólastarfi. Markmiðið um eflingu skólasafnanna er auðveldara að meta. Siljan hefur útvegað skólasöfnunum 1,1 milljón króna til bókakaupa og pannig lagt sitt af mörkum til að rétta hlut safnanna. Keppnin hefur síðast en ekki síst skilað kennurum og öðrum sem sinna lestrarhvatningu auknum skilningi á hvernig börn og unglingar nálgast bókmenntir og hvað hreyfir við peim. Með pví hefur Siljan vonandi greitt leið barna- og ungmennabóka inn í skólastofurnar, eins og kallað hefur verið eftir. 


\section{Siljan - a video competition. Lessons learnt from a reading promotion project}

The video competition Siljan is a creative literacy project developed for 5th-10th grade students by the Centre for Children's Literature at the University of Akureyri. The project involves students creating a video about a recent book for children or adolescents. The objective is to increase interest in reading among students, promote peer support and focus the attention of school communities on books for children and adolescents. The project was initiated in response to the findings of empirical research on literacy among compulsory school students. Research had shown both declining interest in reading and worse performance in tests of reading skills and comprehension. These findings also revealed a substantial gender difference as girls were generally found to be more interested in reading, to have more positive attitudes towards reading and to perform better on standardised tests of reading and comprehension, while boys were more likely to avoid reading. These findings generated substantial concern among educational experts, policy makers and the general public and resulted in various projects to enhance reading skills and literacy. The Siljan project was built around the notion that increasing interest in reading and supporting better reading habits was crucial to enhancing reading comprehension. The video competition was thus developed as a tool to harness the interests and creativity of children and adolescents in projects where they actively engaged with recent children's literature. The competition also generated data that could be used to enhance the reading culture of children and adolescents. The six waves of the competition have generated a database of 230 videos by almost 800 students. In this paper, the Siljan database is used to analyse the students behind the videos with an emphasis on gender and age. Prior research on reading habits among compulsory school students would suggest that girls and younger students would be more likely to participate in such literacy projects. The results confirm these expectations but with a greater slant against older students than expected. Although boys were generally less likely to participate, the incorporation of the competition into teaching resulted in stronger involvement. This underlines the importance of teachers in creating a supportive atmosphere towards reading. The experiences gained from the Siljan project demonstrate the importance of letting children choose and interpret literature as a strategy to support literacy and the teaching of literature. The participants used music, scene cuts, costumes and other strategies to elicit audience response and demonstrated an understanding of literary concepts and abilities to read between the lines that have frequently proven elusive objectives in the classroom. The collection of videos can be seen as a testament to the creative power, ingenuity and technical proficiency among children and a reminder of the importance of reading motivation. The lower rates of participation in Siljan among boys reflect their lower levels of interest in reading and less participation in school work. The videos produced by boys and girls that did participate, however, indicated equivalent levels of immersion, creativity and conceptual richness, suggesting that creative collaborative projects are equally suitable for both boys and girls. Interestingly, the books chosen by students tend to be more akin to best-seller lists where a handful of authors dominate, rather than the children's literature manifested in statistics on school library lending. Book series are prevalent on both best-seller lists and library lending lists, revealing a level of loyalty towards the book characters. The most popular books on both lists tend to be male dominated, especially on the school library list. It is worth mulling over these findings in the context of a pervasive public discourse attributing worse school performance among boys to the feminine slant of schools and classrooms dominated by female teachers and administrators. In this case, the masculine gender bias of children's literature does not seem to generate greater or even equal interest in reading among boys compared to girls.

Keywords: Reading motivation, literacy, creative schools, information technology, teaching literature. 


\section{Um höfund}

Brynhildur Pórarinsdóttir (brynh@unak.is) er dósent við Kennaradeild Háskólans á Akureyri. Hún er stjórnarformaður Barnabókaseturs, rannsóknarseturs um barnabókmenntir og lestur barna við HA. Hún er einnig í stjórn RASK, Rannsóknarstofu um skapandi skólastarf og Rannsóknarstofu um íslensk fræði og íslenskukennslu.

\section{About the author}

Brynhildur Pórarinsdóttir (brynh@unak.is) is an associate professor at the University of Akureyri, Faculty of Education. She leads the Barnabókasetur / Centre for Children's Literature. She is a board member of the RASK, Research Centre for Creative Education and of the Research Centre for Teaching Icelandic.

\section{Heimildir}

Almar Miðvík Halldórsson. (2011). Kynjamunur i námsárangri i grunnskólum Reykjavíkur samkvamt PISA 2009 og samremdum prófum. Menntasvið Reykjavíkur.

Almar M. Halldórsson, Ragnar F. Ólafsson og Júlíus K. Björnsson. (2013). Helstu niðurstöður PISA 2012. Lesi nemenda á sterðfraði og náttúrufreði og lesskilningur. https://mms.is/sites/mms.is/files/pisa_2012_island.pdf

Auður Magndís Leiknisdóttir, Hrefna Guðmundsdóttir, Ágústa Edda Björnsdóttir, Heiður Hrund Jónsdóttir og Friðrik H. Jónsson. (2009). Staða lestrarkennslu i islenskum grunnskólum. https://www.stjornarradid.is/media/ menntamalaraduneyti-media/media/ritogskyrslur/stada_lestrarkennslu_i_islenskum_grunnskolum_2009.pdf

Barnabókasetur. (2020, 27. mars). Lestur er lika smitandi. https://barnabokasetur.is/lestur-er-lika-smitandi/

Bláskógaskóli fékk viðurkenningu fyrir myndband. (2017, 4. maí). Fréttavefur Suðurlands. https://www.dfs. is/2017/05/04/blaskogaskoli-fekk-vidurkenningu-fyrir-myndband/

Brynhildur Pórarinsdóttir. (2011). Er hjartað hætt að slá? Skólabókasöfn á krepputímum. Í Ása Guðný Ásgeirsdóttir, Helga Björnsdóttir og Helga Ólafs (ritstjórar), Djódarspegillinn. Rannsóknir i félagsvísindum XII (bls. 133-140). Félagsvísindastofnun Háskóla Íslands.

Brynhildur Pórarinsdóttir, Andrea Hjálmsdóttir og Póroddur Bjarnason. (2012). Bóklausir og bókaormar: Tengsl menntunar og efnahags foreldra við yndislestur unglinga í alpjóðlegu ljósi. Rádstefnurit Netlu-Menntakvika 2012. http://hdl.handle.net/1946/14529

Brynhildur Pórarinsdóttir, Andrea Hjálmsdóttir og Póroddur Bjarnason. (2017). Yndislestur á uppleið? Breytingar á lestrarvenjum drengja og stúlkna. Netla - Veftimarit um uppeldi og menntun. https://netla.hi.is/greinar/2017/ ryn/06.pdf

Brynhildur Pórarinsdóttir og Kristján Jóhann Jónsson. (2018). Lestur og læsi. Í Kristján Jóhann Jónsson og Ásgrímur Angantýsson (ritstjórar), Íslenska i grunnskólum og framhaldsskólum (bls. 41-82). Háskólaútgáfan.

Dagný Kristjánsdóttir, Jón Yngvi Jóhannsson, Brynhildur Pórarinsdóttir og Kristján Jóhann Jónsson. (2018). Bókmenntir og bókmenntakennsla. Í Kristján Jóhann Jónsson og Ásgrímur Angantýsson (ritstjórar), Íslenska i grunnskólum og framhaldsskólum (bls. 83-134). Háskólaútgáfan.

Daschmann, E. C., Goetz, T. og Stupnisky, R. H. (2014). Exploring the antecedents of boredom: Do teachers know why students are bored? Teaching and Teacher Education, 39, 22-30. https://doi.org/10.1016/j. tate.2013.11.009

Félag íslenskra bókaútgefenda. (2013). Bóksölulistar ársins 2013. https://fibut.is/bokasolulistinn/2013

Félag íslenskra bókaútgefenda. (2014a). Bóksölulistinn 2014. https://fibut.is/bokasolulistinn/2014

Félag íslenskra bókaútgefenda. (2014b). Bókatíðindi 2014. https://fibut.is/attachments/article/122/Bokatidindi2014_LOW.pdf

Félag íslenskra bókaútgefenda. (2015). Bóksölulistinn 2015. https://fibut.is/bokasolulistinn/2015

Félag íslenskra bókaútgefenda. (2016). Bóksölulistinn 2016. https://fibut.is/bokasolulistinn/2016 
Félag íslenskra bókaútgefenda. (2017). Bóksölulistinn 2017. https://fibut.is/bokasolulistinn/2017

Félag íslenskra bókaútgefenda. (2018). Bóksölulistinn 2018. https://fibut.is/bokasolulistinn/2018

Félag íslenskra bókaútgefenda. (2019). Bóksölulistinn 2019. https://fibut.is/bokasolulistinn/2019

Félag íslenskra bókaútgefenda. (2020). Bóksölulistinn 2020. https://fibut.is/bokasolulistinn/2020

Freyja Birgisdóttir. (2016). Orðaforði og lestrarfarni: Tengsl við gengi nemenda i lesskilningshluta PISA. Sérrit Netlu - Um lesi. https:/ojs.hi.is/netla/article/view/2429/1314

Glerárskóli. (2015a, 22. maí). Siljan - sigurvegarar i Glerárskóla. https://glerarskoli.is/siljan-sigurvegarar-i-glerarskola/

Glerárskóli. (2015b, 26. nóvember). Siljan. https://glerarskoli.is/siljan/

Hafdís Guðrún Hilmarsdóttir, Freyja Birgisdóttir og Steinunn Gestsdóttir. (2018). Tengsl lestraráhugahvatar og lesskilnings nemenda á miðstigi grunnskóla. Tímarit um uppeldi og menntun, 27(2), 175-199. https:// ojs.hi.is/tuuom/article/view/2880

Háskólinn á Akureyri. (2015, 11. mars). Siljan - bókapáttur fyrir börn og unglinga. https://www.unak.is/is/ samfelagid/frettasafn/frett/siljan-bokathattur-fyrir-born-og-unglinga

Krakkar bestir í að toga aðra krakka að lestri. (2015). Skólavarðan, 15(7), 22-23. https://timarit.is/ page/6668375\#page/n21/mode/2up

KrakkaRÚV. (2017, 15. maí). Krakkafréttir. https://www.ruv.is/krakkaruv/spila/krakkafrettir/24081/75ku30

Kristín Heba Gísladóttir, Porbjörg Ólafsdóttir, Brynhildur Pórarinsdóttir og Herdís Anna Friðfinnsdóttir. (2013). Lestrarvenjur ungra bókaorma. Barnabókasetur Íslands.

Kristján Jóhann Jónsson. (2013). Skapandi lestur, skilningur og túlkun. Skima, 36(1), 12-17.

Landskerfi bókasafna. (e.d.). Vinsalustu titlarnir [leitarvél]. Sótt af https://www.landskerfi.is/um-okkur/vinsaelustu-titlarnir/vinsaelustu-titlarnir

Lipsyte, R. (2011, 19. ágúst). Boys and reading: Is there any hope? The New York Times. https://www.nytimes. com/2011/08/21/books/review/boys-and-reading-is-there-any-hope.html

Logan, S. og Johnston, R. (2009). Gender differences in reading ability and attitudes: Examining where these differences lie. Journal in Research in Reading, 32, 199-214. https://doi.org/10.1111/j.1467-9817.2008.01389.x

Lög um persónuvernd og vinnslu persónuupplýsinga nr. 90/2018.

Magnús Geir Eyjólfsson. (2021, 25. maí). Lesskilningur drengja vel undir meðaltali OECD. RÚV. https:// www.ruv.is/frett/2021/05/25/lesskilningur-drengja-vel-undir-medaltali-oecd

Mennta- og menningarmálaráðuneyti. (2013). Aðalnámskrá grunnskóla 2011: Almennur hluti: Greinasvið 2013.

Menntamálastofnun. (2019). PISA 2018. Helstu niðurstöður á Íslandi. https://mms.is/sites/mms.is/files/ pisa_2018_helstu_island.pdf

Nordic Council of Ministers. (2012). Northern Lights on PISA 2009 - focus on reading. https://www.norden. org/en/publication/northern-lights-pisa-2009-focus-reading

OECD. (2011). Do students today read for pleasure? PISA in Focus, 8. https://doi.org/10.1787/5k9h362lhw32-en

OECD. (2019). PISA 2018 results (volume I): What students know and can do. https://doi.org/10.1787/5f07c754-en

Rannís. (2013, 11. júní). Úthlutun úr Barnamenningarsjóði. https://www.rannis.is/frettir/nr/2391

Sigríður Ólafsdóttir og Baldur Sigurðsson. (2017). Hnignandi frammistaða íslenskra nemenda í lesskilningshluta PISA frá 2000 til 2015: Leiðir til að snúa próuninni við. Netla - Veftímarit um uppeldi og menntun. http:// netla.hi.is/greinar/2017/ryn/16.pdf

Sigrún Jónatansdóttir, Kristján Ketill Stefánsson, Steinunn Gestsdóttir og Freyja Birgisdóttir. (2017). Má rekja mun á lesskilningi kynjanna til mismikillar pátttöku í skólastarfi? Tímarit um uppeldi og menntun, 26(1-2), 87-109.

Soffía Vagnsdóttir. (2021). Virkjum sköpunarkraft, forvitni, ímyndunarafl og nýsköpun. Skólapraðir. https:// skolathraedir.is/tag/soffia-vagnsdottir/

Unnu bækur fyrir hundrað púsund krónur. (2018, 17. júní). Morgunblaðið, Barnablað. 
Vallaskóli. (e.d.). Siljan 2018 - Vallaskóli meðal vinningshafa. https://vallaskoli.is/siljan-2018-vallaskoli-a-medal-vinningshafal

Verðlaun veitt í Siljunni. (2016, 10. maí). Morgunblaðið. https://www.mbl.is/greinasafn/grein/1595335/

Pingskjal nr. 1455/2020-2021. Svar mennta- og menningarmálarádherra við fyrirspurn frá Ólafi Ísleifssyni um námsárangur pilta og stúlkna i skólakerfinu. https://www.althingi.is/altext/151/s/1455.html

Porbjörn Broddason, Kjartan Ólafsson og Sólveig Margrét Karlsdóttir. (2009). Ný börn og nýir miðlar á nýju árpúsundi. Í Gunnar Pór Jóhannesson og Helga Björnsdóttir (ritstjórar), Rannsóknir í félagsvísindum X: Félags og mannvísindadeild: Erindi futt á rásstefnu i október 2009 (bls. 253-262). Félagsvísindastofnun Háskóla Íslands.

Brynhildur Pórarinsdóttir. (2021).

Myndbandasamkeppnin Siljan: Lærdómur af lestrarhvetjandi verkefni.

Netla - Veftímarit um uppeldi og menntun: Sérrit 2021 - Menntavika 2021.

Sótt af http://netla.hi.is/serrit/2021/menntavika_2021/01.pdf

DOI: https://doi.org/10.24270/serritnetla.2021.1 